\title{
To Study the Comparison of Liver Function Variables among Type-2 Diabetic Patients and Non Diabetic Subjects in a Tertiary Care Hospital of Western Rajasthan
}

Miss. Pooja ${ }^{1 *}$, Dr. Jairam Rawtani ${ }^{2}$, Mr. Vasudev Sankhla ${ }^{3}$

${ }^{1}$ M.Sc (Medicine) Biochemistry, Department of Biochemistry, Dr. Sampurnand Medical College Jodhpur (342001), Rajasthan, India

${ }^{2}$ Senior Professor \& Head, Department of Biochemistry, Dr. Sampurnand Medical College Jodhpur (342001), Rajasthan, India

${ }^{3}$ Senior Demonstrator, Department of Biochemistry, Government Medical College, Pali (306401), Rajasthan, India

*Corresponding author: Miss Pooja

Abstract

Diabetes mellitus is a Chronic metabolic disorder characterized by the presence of hyperglycemia due to defective insulin secretion, defective insulin action or both. This study was conducted to find out the prevalence of the various liver disease in the Type 2 Diabetic Patients. Total 96 subjects were enrolled, 48 Type 2 Diabetic Patients and 48 Non Diabetic subjects. There were significantly increase serum Glucose, serum Alaninine Transaminase, serum Aspartate Transaminase, serum Alkaline Phosphatase and Serum Gamma Glutamyl Transpeptidase in Type 2 Diabetic subjectes while a statistically non-significant difference were observed in the serum Total Protein, serum Albumin and serum Total Bilirubin in Type-2 diabetic subjects.

Keywords: Type 2 Diabetic Patients, Liver Disease.

Copyright $($ C) 2021 The Author(s): This is an open-access article distributed under the terms of the Creative Commons Attribution 4.0 International License (CC BY-NC 4.0) which permits unrestricted use, distribution, and reproduction in any medium for non-commercial use provided the original author and source are credited.

\section{INTRODUCTION}

Diabetes mellitus is a chronic metabolic disorder characterized by absolute or relative deficiencies in insulin secretion and/ or insulin action associated with chronic hyperglycemia and disturbances of carbohydrate, lipid and protein metabolism [1]. According to International Diabetes Federation there were 41 million diabetic patients in India (2006) which are projected to raise to 70 million in 2025 . Out of these more than $90 \%$ are type-2 diabetic patients [2]. The global burden of diabetes mellitus is enormous with an estimated 366 million people worldwide.

Type-2 diabetes mellitus is also called as non insulin dependent diabetes mellitus (NIDDM) is initially caused due to decreased sensitivity of target tissues to metabolic effects of insulin. This reduced insulin sensitivity of insulin in cells is often referred to as Insulin resistance [3].

The scope of liver disease in type-2 diabetes includes abnormal liver enzymes and non-alcoholic fatty liver disease (NAFLD), cirrhosis, hepatocellular carcinoma (HCC), acute liver failure [4]. ALT and AST are the well-known markers of hepatocellular health while GGT also shows biliary tract function. ALT is most specific marker of liver function, but AST and GGT are the less specific markers because they are present in other tissues $[5,6]$.

\section{Material And Method}

This study was unmatched case-control study design, conducted 96 subjects of either sex and > 30 year age group, attending the out patients clinical of Department of Biochemistry, Dr. S.N. Medical College and its Associated Group of Hospitals, Jodhpur in the year 2019.

The subjects were grouped:

Group1: 48 Type-2 diabetic subjects

Group2: 48 Non diabetic subjects

An ethical clearance was obtained from the ethical committee of Dr. S. N. Medical College, Jodhpur.

After overnight fast of 10-12 hours, $5 \mathrm{ml}$ of venous blood sample will be collected from all the subjects from antecubital vein by using aseptic techniques. Plasma glucose was measured by Endpoint 
Miss Pooja et al; Sch J App Med Sci, Mar, 2021; 9(3): 367-371

Enzymatic Glucose oxidase and peroxidase [GODPOD] method. Serum Total Protein was measured by Biuret method. Serum Albumin was measured by Bromocresol Green method. Serum Total Bilirubin was measured by Diazo method. Serum Alanine Transaminase, Aspartate Transaminase and Alkaline Phosphatase were measured by (IFFC) International Federation of Clinical Chemistry. Serum Gamma Glutamyl Transpeptidase was measured by (GLUPA-C) L- $\gamma$-Glutamyl-3-carboxy-p-nitroanilide.

\section{STATISTICAl ANAlysis}

The data assembled for different biochemical parameters were subjected to suitable statistical analysis to compute central tendencies (mean) and accompanying measures of variability statistics (standard deviation) for all the groups. The magnitude of inter group differences for each of the parameters was quantified by using student's compute ' $t$ ' test values (Student's ' $t$ ' test). On the basis of t-values, ' $p$ ' values (probability) were determined to find out significance of variance between the mean values of individual parameters among the groups of subjects studied [7].

\section{RESULT}

The present study was conducted on 98 subjects of either sex and different age groups (31-70), comprising of 48 Type- 2 diabetic subjects (24 male and 24 female) and 48 non diabetic subjects ( 24 male and 24 female).

Among the biochemical parameters mean fasting plasma Glucose, Serum Alanine Transaminase, Serum Aspartate Transaminase, Serum Alkaline Phosphatase and Serum Gamma Glutamyl Transpeptidase level of Type 2 Diabetic Patients were significantaly higher as compared to Non Diabetic Subjects, while Serum Total Protein, Serum Albumin, Serum Total Bilirubin level of Type 2 Diabetic Patients were non significant as compared to Non Diabetic Subjects as showen in Table 1 and 2.

Table-1: Mean Fasting Plasma Glucose and Liver Function Test of the subjects studied

\begin{tabular}{|c|c|c|c|c|}
\hline & Group Studied & Male & Female & Total \\
\hline \multirow[t]{2}{*}{$\begin{array}{l}\text { Fasting Plasma Glucose } \\
(\mathrm{mg} / \mathrm{dl})(\text { Mean } \pm \text { S.D. })\end{array}$} & Non Diabetic Subjects(48) & $\begin{array}{l}93.83 \pm 10.89 \\
(79-111)\end{array}$ & $\begin{array}{l}91.16 \pm 11.54 \\
(77-112)\end{array}$ & $\begin{array}{l}92.50 \pm 11.15 \\
(77-112)\end{array}$ \\
\hline & Type-2 Diabetic Patients(48) & $\begin{array}{l}201.62 \pm 38.36 \\
(140-278)\end{array}$ & $\begin{array}{l}192.16 \pm 35.66 \\
(135-256)\end{array}$ & $\begin{array}{l}196.9 \pm 36.95 \\
(135-278)\end{array}$ \\
\hline \multirow[t]{2}{*}{$\begin{array}{l}\text { Total Protein Level }(\mathrm{gm} / \mathrm{dl}) \\
(\text { Mean } \pm \text { S.D. })\end{array}$} & Non Diabetic Subjects(48) & $\begin{array}{l}7.06 \pm 0.34 \\
(6.4-7.7)\end{array}$ & $\begin{array}{l}6.96 \pm 0.42 \\
(5.9-7.47)\end{array}$ & $\begin{array}{l}7.01 \pm 0.38 \\
(5.9-7.47)\end{array}$ \\
\hline & Type-2 Diabetic Patients(48) & $\begin{array}{l}6.94 \pm 0.45 \\
(5.9-7.5)\end{array}$ & $\begin{array}{l}6.83 \pm 0.40 \\
(5.8-7.2)\end{array}$ & $\begin{array}{l}6.88 \pm 0.42 \\
(5.8-7.5)\end{array}$ \\
\hline \multirow{2}{*}{$\begin{array}{l}\text { Serum Albumin Level } \\
(\text { gm/dl) } \\
(\text { Mean } \pm \text { S.D. })\end{array}$} & Non Diabetic Subjects(48) & $\begin{array}{l}4.49 \pm 0.35 \\
(3.9-5)\end{array}$ & $\begin{array}{l}4.46 \pm 0.32 \\
(3.8-4.9)\end{array}$ & $\begin{array}{l}4.47 \pm 0.33 \\
(3.8-5)\end{array}$ \\
\hline & Type-2 Diabetic Patients(48) & $\begin{array}{l}4.43 \pm 0.31 \\
(4-4.92)\end{array}$ & $\begin{array}{l}4.37 \pm 0.37 \\
(3.8-4.9)\end{array}$ & $\begin{array}{l}4.40 \pm 0.34 \\
(3.8-4.92) \\
\end{array}$ \\
\hline \multirow{2}{*}{$\begin{array}{l}\text { Serum Total Bilirubin } \\
\text { Level (mg/dl) } \\
\text { (Mean } \pm \text { S.D.) }\end{array}$} & Non Diabetic Subjects(48) & $\begin{array}{l}0.64 \pm 0.20 \\
(0.29-0.95)\end{array}$ & $\begin{array}{l}0.61 \pm 0.18 \\
(0.23-0.88)\end{array}$ & $\begin{array}{l}0.63 \pm 0.19 \\
(0.23-0.95)\end{array}$ \\
\hline & Type-2 Diabetic Patients(48) & $\begin{array}{l}0.66 \pm 0.20 \\
(0.20-0.99)\end{array}$ & $\begin{array}{l}0.62 \pm 0.18 \\
(0.37-0.98)\end{array}$ & $\begin{array}{l}0.64 \pm 0.19 \\
(0.20-0.99)\end{array}$ \\
\hline \multirow[t]{2}{*}{$\begin{array}{l}\text { Serum ALT Level (U/L) } \\
(\text { Mean } \pm \text { S.D.) }\end{array}$} & Non Diabetic Subjects(48) & $\begin{array}{l}21.75 \pm 6.89 \\
(8-36)\end{array}$ & $\begin{array}{l}20.87 \pm 6.82 \\
(11-33)\end{array}$ & $\begin{array}{l}21.31 \pm 6.80 \\
(8-36)\end{array}$ \\
\hline & Type-2 Diabetic Patients(48) & $\begin{array}{l}38.20 \pm 5.81 \\
(23-44)\end{array}$ & $\begin{array}{l}36.20 \pm 5.27 \\
(23-42)\end{array}$ & $\begin{array}{l}37.20 \pm 5.58 \\
(23-44)\end{array}$ \\
\hline \multirow[t]{2}{*}{$\begin{array}{l}\text { Serum AST Level (U/L) } \\
\text { (Mean } \pm \text { S.D.) }\end{array}$} & Non Diabetic Subjects(48) & $\begin{array}{l}28.29 \pm 7.80 \\
(12-38)\end{array}$ & $\begin{array}{l}25.41 \pm 6.94 \\
(15-38)\end{array}$ & $\begin{array}{l}26.85 \pm 7.61 \\
(12-38)\end{array}$ \\
\hline & Type-2 Diabetic Patients(48) & $\begin{array}{l}35.87 \pm 4.54 \\
(27-42)\end{array}$ & $\begin{array}{l}36.87 \pm 3.69 \\
(29-41)\end{array}$ & $\begin{array}{l}36.37 \pm 4.12 \\
(27-42)\end{array}$ \\
\hline \multirow[t]{2}{*}{$\begin{array}{l}\text { Serum ALP Level (U/L) } \\
(\text { Mean } \pm \text { S.D.) }\end{array}$} & Non Diabetic Subjects(48) & $\begin{array}{l}99.37 \pm 26.05 \\
(63-142)\end{array}$ & $\begin{array}{l}83.45 \pm 22.74 \\
(56-142)\end{array}$ & $\begin{array}{l}91.41 \pm 25.49 \\
(56-142)\end{array}$ \\
\hline & Type-2 Diabetic Patients(48) & $\begin{array}{l}139.33 \pm 27.06 \\
(75-165)\end{array}$ & $\begin{array}{l}147.25 \pm 23.10 \\
(86-167)\end{array}$ & $\begin{array}{l}143.29 \pm 25.21 \\
(75-167)\end{array}$ \\
\hline \multirow[t]{2}{*}{$\begin{array}{l}\text { Serum GGT Level (U/L) } \\
\text { (Mean } \pm \text { S.D.) }\end{array}$} & Non Diabetic Subjects(48) & $\begin{array}{l}21.75 \pm 7.31 \\
(11-34)\end{array}$ & $\begin{array}{l}18.83 \pm 5.00 \\
(11-28)\end{array}$ & $\begin{array}{l}20.29 \pm 6.37 \\
(11-34)\end{array}$ \\
\hline & Type-2 Diabetic Patients(48) & $\begin{array}{l}37.45 \pm 2.04 \\
(34-40)\end{array}$ & $\begin{array}{l}27.91 \pm 2.33 \\
(24-30)\end{array}$ & $\begin{array}{l}32.68 \pm 5.28 \\
(24-40)\end{array}$ \\
\hline
\end{tabular}


Table-2: Statistical analysis of Fasting Plasma Glucose and Liver Function Test Level among the groups studied

\begin{tabular}{|l|l|l|}
\hline \multirow{2}{*}{ Group studied } & \multicolumn{2}{l|}{ Non Diabetic subjects v/s Type 2 Diabetic Patients } \\
\cline { 2 - 3 } & t-value & p-value \\
\hline Fasting Plasma Glucose & 18.7346 & $\begin{array}{l}<0.0001 \\
(\text { HS) }\end{array}$ \\
\hline Serum Total Protien & 1.590 & $\begin{array}{l}0.115 \\
\text { (NS) }\end{array}$ \\
\hline Serum Albumin & 1.023 & $\begin{array}{l}0.308 \\
\text { (NS) }\end{array}$ \\
\hline Serum Total Bilirubin & 0.257 & $\begin{array}{l}0.7971 \\
\text { (NS) }\end{array}$ \\
\hline Serum Alanine Transaminase & 12.5153 & $\begin{array}{l}<0.0001 \\
(\mathbf{H S})\end{array}$ \\
\hline Serum Aspartate Transaminase & 7.62177 & $\begin{array}{l}<0.0001 \\
(\mathbf{H S})\end{array}$ \\
\hline Serum Alkaline Phosphatase & 10.0258 & $\begin{array}{l}<0.0001 \\
(\mathbf{H S})\end{array}$ \\
\hline Serum Gamma Glutamyl Transpeptidase & 10.375 & $\begin{array}{l}<0.0001 \\
(\mathbf{H S})\end{array}$ \\
\hline
\end{tabular}

HS-Highly Significant, NS- Non Significant

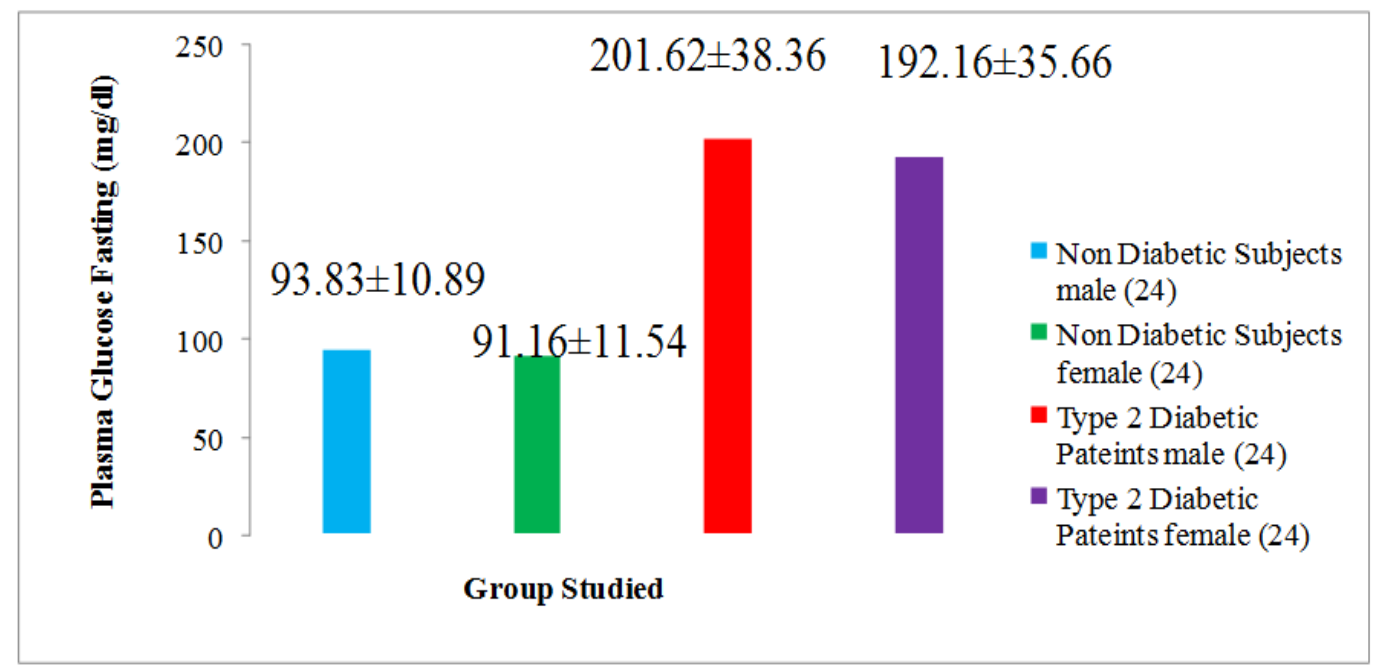

Fig-1: Mean Plasma Glucose Fasting (mg/dl) of Subjects Studied

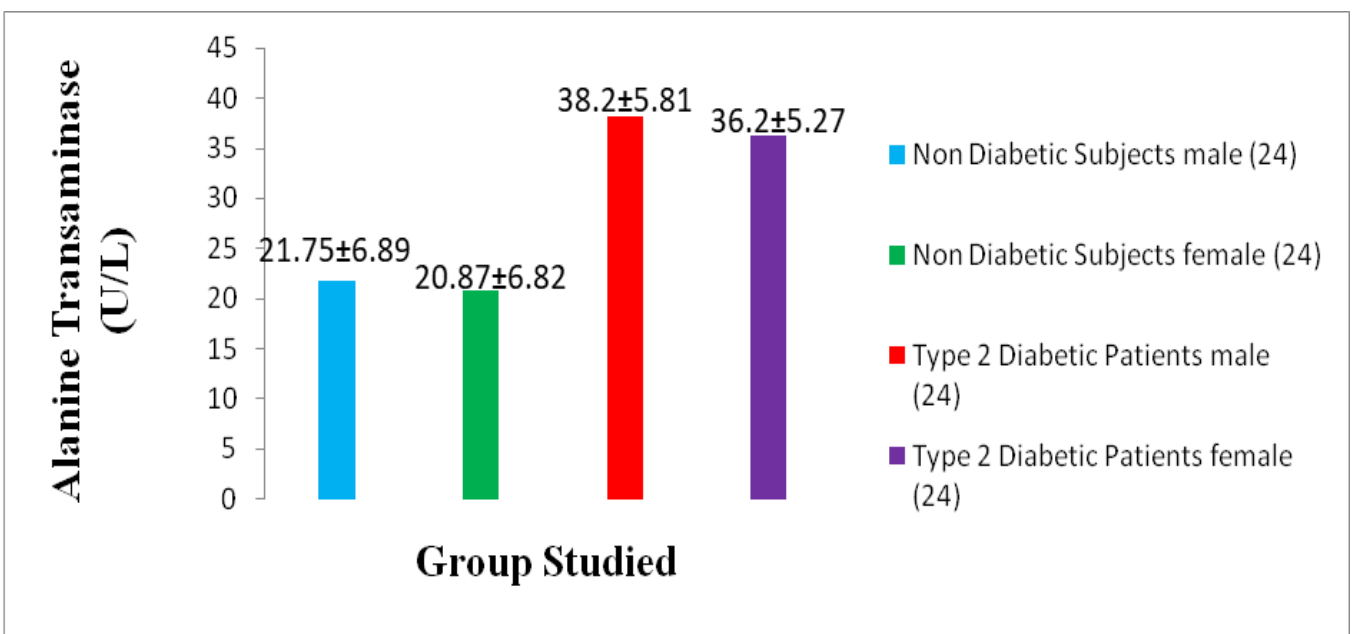

Fig-2: Mean Serum Alanine Transaminase (U/L) of Subjects Studied 
Miss Pooja et al; Sch J App Med Sci, Mar, 2021; 9(3): 367-371

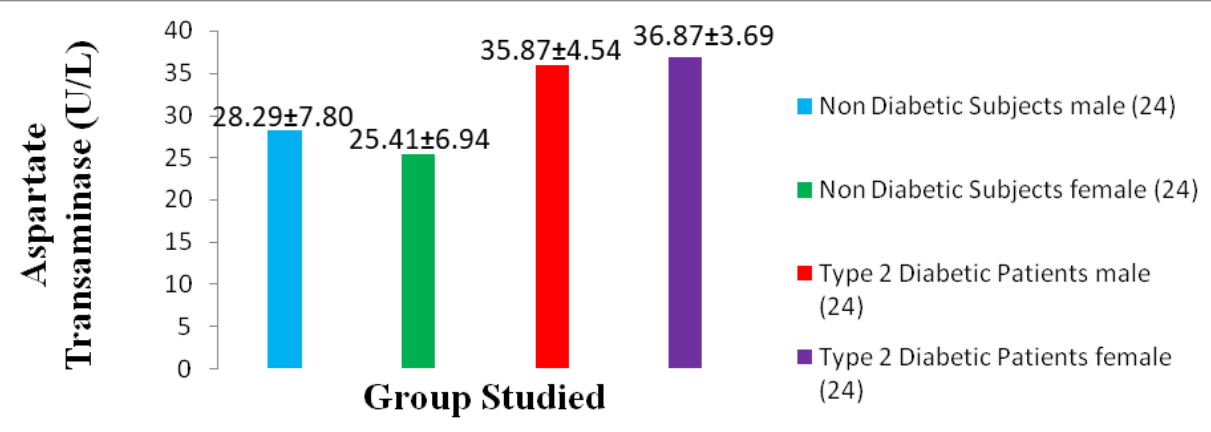

Fig-3: Mean Serum Aspartate Transaminase (U/L) of Subjects Studied

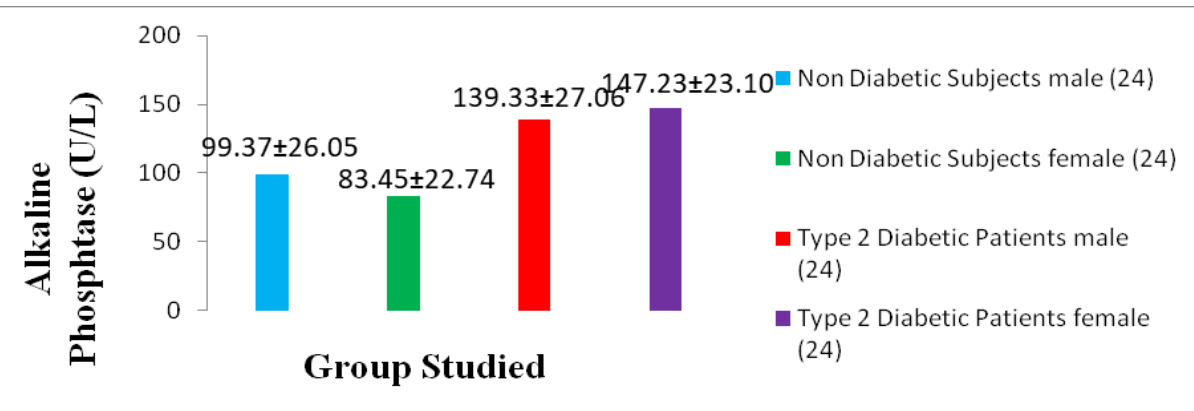

Fig-4: Mean Serum Alkalin phosphatase (U/L) of Subjects Studied

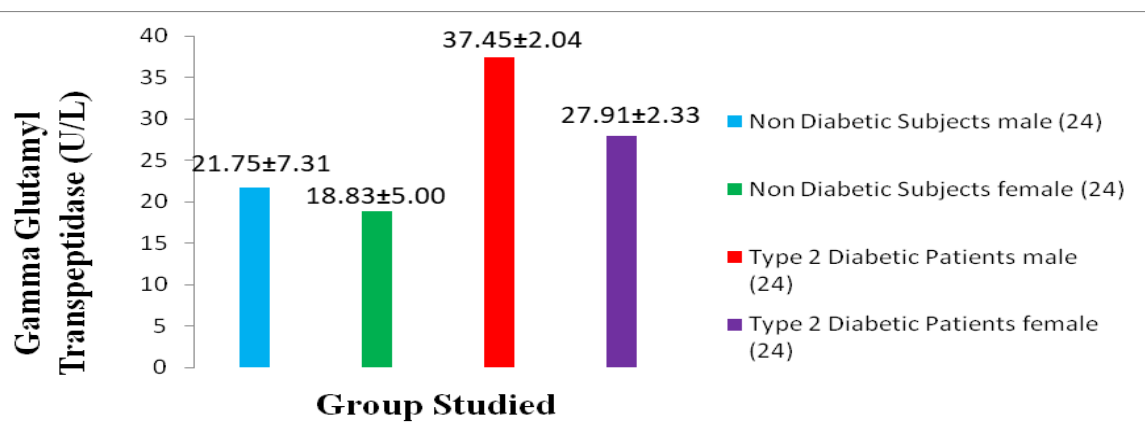

Fig-5: Mean Serum Gamma Glutamyl Transpeptidase (U/L) of Subjects Studied

\section{DISCUSSION}

Diabetes mellitus is often simply considered as a syndrome of disordered metabolism with abnormally high blood glucose levels (hyperglycemia). Besides the microvascular and macrovascular complications in DM a compromised immune state is also a condition that increases the susceptibility of a diabetic patient to different infections.

Liver dysfunction associated with elevated liver enzymes is frequently encountered in type 2 diabetes mellitus. Chronic liver disease is an important cause of death in type 2 diabetes patients.

In our study, a statistically highly significant elevated fasting glucose plasma level was observed in Type-2 diabetic subjects $(\mathrm{t}=18.7346, \mathrm{p}<0.0001)$ when results were compared with non diabetic subjects (Table-2). Our study similar with Keshab Raj Joshi and Harno $\mathrm{K}$ et al., [8, 9] found that the fasting blood glucose levels was found to be significantly $(p<0.02)$ high in Type -2 diabetic mellitus patients, than control.

In our study, a statistically non-significant difference were observed in the serum Total Protein $(\mathrm{t}=1.590, \mathrm{p}=0.115)$ and serum Albumin $(\mathrm{t}=1.023, \mathrm{p}$ $=0.308)$ of Type- 2 diabetic subjects when results were compared with non diabetic subjects. Our study similar with Sunitha $\mathrm{S}$ et al., [10] found non-significant difference in the serum Total Protein and serum Albumin of Type-2 diabetic subjects as compared with non diabetic controls.

In our study, a statistically non-significant variation was observed in the serum Total Bilirubin of Type-2 diabetic subjects $(\mathrm{t}=0.257, \mathrm{p}=0.7971)$ when results were compared with non diabetic subjects Table2.

A statistically very significant increase was observed in the serum Alanine Transaminase $(\mathrm{t}=12.5153, \mathrm{p}<0.0001)$ and Aspartate Transaminase 
Miss Pooja et al; Sch J App Med Sci, Mar, 2021; 9(3): 367-371

$(\mathrm{t}=7.62177, \mathrm{p}<0.0001)$ of Type-2 diabetic subjects when results were compared with non diabetic subjects (Table-2). Our study similar with Agarawal J [11] reported that serum levels of ALT was significantly elevated in Type-2 diabetes mellitus patients as compared to controls $(\mathrm{p}<0.05)$ and Sunitha $\mathrm{S}$ et al., [10] also reported abnormal liver enzymes in Type-2 diabetics but patients are asymptomatic.

In our study, a statistically very significant increase was observed in the serum Alkaline Phosphate of Type-2 diabetic subjects $(\mathrm{t}=10.0258, \mathrm{p}<0.0001)$ when results were compared with non diabetic subjects (Table-2). Our study similar with Agarawal J [11] reported that serum levels of ALP was significantly elevated in Type-2 diabetes mellitus patients as compared to controls $(\mathrm{p}<0.05)$.

In our study, a statistically very significant increase was observed in the serum Gamma Glutamyl Transpeptidase levels in Type-2 diabetic subjects $(\mathrm{t}=10.375, \mathrm{p}<0.0001)$ when results were compared with non diabetic subjects (Table-2). Our study similar with Agarawal J [11] and Mathur S et al., [12] reported that serum levels of GGT was significantly elevated in Type-2 diabetes mellitus patients as compared to controls $(\mathrm{p}<0.05)$.

The evaluation of liver enzymes in diabetics showed higher activities than non diabetic individuals. The GGT is known as a marker of hepatobiliary disorders and is associated with diabetes mellitus. Thus controlling liver enzymes can play a pivotal role in reducing morbidity and mortality of Type- 2 diabese patients.

Our results of liver function tests are in accordance with the studies of Sunitha S et al., 2015, and Agarawal J 2015. Thus routine analysis of liver enzymes specially SGPT and GGT can help in early detection of liver injury in type-2 diabetic patients and regulating these parameters can prevent chronic complications and co-morbid abnormalities in type-2 diabetes mellitus subjects.

\section{CONCLUSION}

Indians have a high genetic predisposition for diabetes. In comparison to non-diabetic subjects diabetic patients are more prone to cluster associated biochemical and metabolic abnormalities. Proper and timely analysis of biochemical parameters and early diagnosis can reduces the occurrence of micro vascular and macro vascular complications and lead to decrease the morbidity and mortality from dreadful diabetes mellitus.
There are evidences of elevated level of liver enzymes activity in type- 2 diabetes. Routine analysis of liver enzymes in type-2 diabetics helps in early detection and prevention of liver injury.

\section{REFERENCES}

1. Abou-Seif MA, Youssef AA. Evaluation of some biochemical changes in diabetic patients. Clin Chim Acta. 2004; 346(2):161-170.

2. Sicree R, Shaw J, Zimmet P. Diabetes and impaired glucose tolerance. In: Gan D, Diabetes Atlas. International Diabetes Federation. 2006;3:15-103.

3. Hinge CR, Ingle SB, Adgaonkar BD. Body Mass Index, Blood Pressure and Lipid profile in type 2 diabetes-Review. Int J Cur Res Rev. 2018 May;10(10):1-10.

4. Tolman KG, Fonseca V, Dalpiaz A, Tan MH. Spectrum of liver disease in type-2 diabetes and management of patients with diabetes and liver disease. Diabetes Care. 2007;30(3): 734-743.

5. Lee DH, Silventonein K, Jacobs DR, Jousilhati P, Tuomileto J. Gamma glutamyltransferase, obesity and the risk of type-2 diabetes observational cohort study among 20,158 middle aged men and women. J Clin Endocrinol Metab. 2004;89(11): 5410-5414.

6. Lee DH, Ha MH, Kim JH, Christiani DC, Gross MD, Steffes M, Blomhoff R, Jacobs DR. Gamma glutamyl transferase and diabetes a four year follow up study. Diabetologia. 2003,46(3): 359364.

7. Mahajan BK, Lal S. Methods in biostatistics for medical students and research workers. Indian Journal of Community Medicine. 1999 Jul 1;24(03):140.

8. Barter PJ, Brewer Jr HB, Chapman MJ, Hennekens CH, Rader DJ, Tall AR. Cholesteryl ester transfer protein: a novel target for raising HDL and inhibiting atherosclerosis. Arteriosclerosis, thrombosis, and vascular biology. 2003 Feb 1;23(2):160-167.

9. Howard BV. Lipoprotein metabolism in diabetes mellitus. Journal of lipid research. 1987 Jun 1;28(6):613-628.

10. Kashinakunti SV, Rangappa M, Kallaganada GS. Correlation between liver enzymes and lipid profile in type II diabetes mellitus-A case control study. IOSR-JBB. 2017; 3(5):1-5.

11. Tangvarasittichai S. Oxidative stress, insulin resistance, dyslipidemia and type 2 diabetes mellitus. World journal of diabetes. 2015;6(3):456-459.

12. Shipra M, Debij K M, Sangeeta K and Sushil Y. Liver function in type-2 diabetes mellitus patients. Int J Sci Stud. 2016; 3 (10):43-47. 